PSYCHOLOGIA ROZWOJOWA, $2019 *$ tom 24 , nr 4, s. 57-70

doi:10.4467/20843879PR.19.022.11728

www.ejournals.eu/Psychologia-Rozwojowa

MAGDALENA POŻARSKA-ZARZECKA (iD orcid.org/0000-0002-2147-1309

Szpital Ogólny im. dr Witolda Ginela w Grajewie, Centrum Zdrowia Psychicznego

General Hospital named after dr Witold Ginel in Grajewo

magdapz@poczta.onet.pl

PIOTR OLEŚ

Instytut Psychologii, Katolicki Uniwersytet Lubelski Jana Pawła II

The John Paul II Catholic University of Lublin

oles@kul.pl

\title{
Dobrostan psychologiczny, postawy egzystencjalne i bilans życia w wieku starszym
}

\author{
Psychological Well-Being, Life Attitudes and Life Assessment \\ in Old Age
}

\begin{abstract}
This study assesses the relationship between psychological well-being and life attitudes among older adults, while also providing a psychological analysis of life review questionnaires of 148 participants over 60 years of age (99 female). Quantitative research was conducted by means of Reker's Life Attitudes Profile (LAP) and the Scales of Psychological Well-Being (PWB) by Ryff and Singer. The results confirmed the hypothesis that psychological well-being and life attitudes are positively correlated. Qualitative data were gathered by means of Life Review Interview (LRI). Selfnarratives of senior citizens $(n=70)$, both older adults $(60-69)$ and the elderly $(70-101)$, revealed the predominance of topics related to life values, attitudes toward life and death, and changes during the course of life. Participants who assessed their life positively in LRI obtained higher scores in Environmental Mastery and Personal Growth than participants who assessed their life negatively or ambivalently; no differences were observed in life attitudes between these two groups.
\end{abstract}

Keywords: life revue, meaning of life, psychological well-being, life attitudes, integration, old age

Słowa kluczowe: bilans życia, poczucie sensu życia, dobrostan psychologiczny, postawy egzystencjalne, integracja, starość

\section{DOBROSTAN PSYCHOLOGICZNY, POSTAWY EGZYSTENCJALNE I BILANS ŻYCIA W WIEKU STARSZYM}

Coraz większy odsetek społeczeństwa stanowią ludzie w późnej dorosłości i starości. Są grupa społecznej troski, kiedy myślimy o zjawisku ageizmu, sytuacji społeczno-ekonomicznej osób starszych, a zarazem propagujemy modele pomyślnego starzenia się. Jednocześnie wiele zagadnień i zjawisk związanych ze starzeniem się wymaga dogłębnych badań, podczas gdy publikacji dotyczących grupy wiekowej $60+$ nie ma tak wiele, jak w odniesieniu do innych okresów rozwojowych.

$\mathrm{W}$ artykule tym przedstawiamy badanie składające się z dwóch części. Pierwsza, kwestionariuszowa, dotyczy powiązań między 
dobrostanem psychologicznym i postawami egzystencjalnymi osób powyżej 60 . roku życia. Druga część to jakościowe badanie treści składających się na bilans życia osób starszych. Chodzi w niej o porównanie zawartości wywiadów dotyczących bilansu życia przeprowadzonych z osobami w okresie późnej dorosłości (60-69 lat) i starości (70-101 lat) - porównanie zwłaszcza pod kątem treści istotnych dla pozytywnego bilansu życia.

Starzenie się jest procesem, którego rzeczywisty sens polega na przystosowaniu się do strat związanych ze zmianami w sferze fizycznej, psychologicznej i społecznej; jednocześnie jest to okres pozwalający na osiągnięcie mądrości i na całościową refleksję nad życiem (Steuden, 2011; Straś-Romanowska, 2011). W tym kontekście pojawiają się pytania dotyczące spełnienia oraz jakości i sensu życia. Według Susułowskiej (1989) o zadowoleniu z życia możemy mówić w różnych jego okresach, o bilansie życiowym natomiast wtedy, kiedy oceniamy osiagnięcia i porażki z dłuższej perspektywy czasu.

Zgodnie z teorią selektywnej optymalizacji z kompensacją adaptacyjne starzenie się polega na wyborze tych sfer aktywności oraz celów i dążeń, w których utrzymanie aktywności lub jej rozwój jest możliwy i preferowany przez osobę. Skupienie się na tym, co ważne i osiągalne, jest nie tylko wysoce adaptacyjne, ale także pośrednio służy umocnieniu samooceny (Baltes, Baltes, 1990). Jednocześnie tak zwana kontrola wtórna, czyli decyzje o wycofaniu się z niektórych form aktywności, zmniejszeniu jej, poniechaniu niektórych dążeń (Heckhausen, 1999) wymaga kompensowania tych niezamierzonych, ale koniecznych strat zaangażowaniem w to, co możliwe i osiagalne.

Bilans oznacza ,konstruowanie i rekonstruowanie, interpretację i reinterpretację, ewaluację i rewaluację życia jednostki" (Staudinger, Smith, Baltes, 1992, s. 272). Może być rozumiany jako całościowe podsumowanie, w jakim stopniu życie było udane, sensowne i szczęśliwe, obejmujące realizację celów i zadań, a także wiele zjawisk, wydarzeń i doświadczeń, które zdaniem osoby wpłynęły na jej życie (Butler, 1963; Oleś, 2012). Bilans jest w dużej mierze pochodną aspiracji (Steuden, 2011); dotyczy to zarówno subiektywnie ważnych sfer życia, jak i oczekiwanego poziomu osiągnięć lub funkcjonowania w tych sferach, na przykład rodzina i wychowanie dzieci versus dokonania zawodowe i prestiż społeczny. Biorąc jednak pod uwagę zmiany w zakresie priorytetów i wartości życiowych w biegu życia, a zwłaszcza w okresie starości (Straś-Romanowska, 2011), punktem odniesienia dla bilansu dokonywanego u schyłku życia mogą być inne aniżeli preferowane wcześniej, w okresie średniej i późnej dorosłości, wartości.

Starość jest ostatnim stadium rozwoju człowieka, w którym ego wykształca jakość integracji (versus rozpaczy) (Erikson, 2002). Autorefleksja nad życiem może prowadzić do pozytywnej oceny własnej egzystencji, to jest opracowania spójnej historii życia, albo do oceny negatywnej - w postaci poczucia bezsensu i rozpaczy. Integracja oznacza spójność, poczucie sensu oraz pozytywną interpretację życia; rozpacz - to poczucie braku sensu, celu i perspektyw. Ludzie odnajdują sens w dążeniu do celu, samorealizacji lub w aktywności będącej wyrazem troski o dobro i szczęście innych (Adler, 1986; Bühler, 1999; Maslow, 1986; Obuchowski, 2000). Proces odnajdywania i nadawania życiu sensu ma istotne znaczenie dla integracji i poczucia wewnętrznej spójności, dlatego stanowi węzłowy problem bilansu życia (Reker, Chamberlain, 2000; Straś-Romanowska, 2011). Osiagnnięcie integracji w znacznym stopniu zależy od rozstrzygnięć wcześniejszych kryzysów rozwojowych, ale też od umiejętności reinterpretacji zdarzeń życiowych, łącznie z trudnymi i wcześniej niezrozumiałymi.

Bilans życia może dotyczyć zysków i strat w biegu życia, w tym także: realizacji celów i dążeń osobistych; sensowności i użyteczności przekonań i postaw dotyczących siebie, ludzi i świata; skuteczności radzenia sobie z trudnymi doświadczeniami; jakości relacji z ludźmi oraz innych subiektywnie ważnych kwestii, takich jak na przykład rozwój osobisty czy decydowanie o własnym życiu (autonomia) (Ryff, 2014). Bilans oznacza bowiem pogłębioną refleksję nad życiem, w znacznym stopniu przeżytym; może obejmować okoliczności, które miały wpływ 
na bieg życia i wybory człowieka (Oleś, 2012; Steuden, 2011). I choć podsumowań można dokonywać na każdym etapie życia, to jednak całościowy bilans wydaje się typowy dla tak zwanej jesieni życia, czyli po przekroczeniu 60. lub 70. roku życia. I właśnie tego zjawiska dotyczą badania przedstawione w tym artykule.

\section{PROBLEM BADAŃ}

Badania miały na celu: (1) sprawdzenie współzależności między dobrostanem psychologicznym a postawami egzystencjalnymi oznaczającymi w przybliżeniu poczucie sensu życia oraz (2) eksplorację treści bilansu życia osób w wieku 60-101 lat. W pierwszej części badania chodziło o sprawdzenie, czy istnieje i jak silny jest związek między poczuciem sensu życia a dobrostanem psychologicznym. Hipoteza jest następująca:

H.1. Między dobrostanem psychologicznym a nasileniem postaw egzystencjalnych istnieje dodatnia korelacja, wysoka lub co najmniej umiarkowana.

Dobrostan psychologiczny zawiera między innymi takie komponenty, jak refleksja nad życiem i autonomiczny wybór wartościowych celów (Ryff, 2014), stąd powiązanie z poczuciem sensu życia jest w pełni uzasadnione. Co więcej, badanie osób, które mogą dokonywać bilansu życia, czyli są na etapie integrowania historii życia, pozwala oczekiwać, że zmienne nasycone egzystencjalnie i dobrostan psychologiczny są ze sobą silnie powiązane.

Druga część badań ma charakter eksploracyjny, dotyczy tego, jakie kwestie przywoływali badani, kiedy byli pytani o bilans życia. $\mathrm{W}$ jakim zakresie są one podobne, a w jakim różne w okresie późnej dorosłości (60-69 lat) i starości (70-101 lat)? W bilansie życia można oczekiwać odniesień do wartości życiowych, spełnionych i niepełnionych aspiracji, stylu życia, zysków i strat, a może także odniesień do kwestii zdrowia lub lęku przed śmiercią (Susułowska, 1989). Jednocześnie wiek badanych: 60-69 lat versus 70+ sugeruje, iż z uwagi na kondycję fizyczną i stan zdrowia, sytuację społeczną i psychologiczna, w tym powtarza- jące się doświadczenia straty (rówieśników) oraz świadomość nieuchronnie zbliżającej się śmierci treści wypowiedzi osób z grupy starszej mogą różnić się od wypowiedzi osób młodszych.

W tej części badania dodatkowo można było sprawdzić, czy osoby odmiennie oceniające własne życie w wywiadzie różnią się także pod względem nasilenia postaw egzystencjalnych lub dobrostanu psychologicznego. W odniesieniu do tego pytania postawiono hipotezę:

H.2. Poczucie sensu życia i dobrostan są istotnie wyższe u osób, których bilans jest pozytywny, w porównaniu z osobami, których bilans jest ambiwalentny lub negatywny.

Uzasadnienie tej hipotezy wiąże się z faktem, iż osoby uzyskujące integrację akcentują dokonania życiowe, wartościowe wybory i związki interpersonalne, poczucie spełnienia oraz spójność historii życia, co łączy się z pozytywną oceną życia, a zarazem z poczuciem jego sensu, i z dobrostanem psychologicznym (Reker, 1992; Ryff, 2014). Tymczasem osoby bliskie rozpaczy moga skupiać się na treściach dotyczących porażek, błędów, nieudanych związków interpersonalnych, niewłaściwych decyzji czy niespójnych przekonań i postaw (Erikson, 2002), co może się przekładać na negatywną ocenę życia oraz mniejsze nasilenie postaw egzystencjalnych i niski dobrostan psychologiczny.

\section{OSOBY BADANE}

Uczestnikami pierwszej części badania było 148 osób: 99 kobiet i 49 mężczyzn w wieku 60-101 lat. Dobrano je incydentalnie metodą kuli śnieżnej, w większości były nieaktywne zawodowo, mieszkały w Białymstoku i okolicach. Średnia wieku wynosiła: $M=67.53 ; S D=6.95$ (kobiety: $M=67.41 ; S D=7.16$; mężczyźni: $M=67.78$; $S D=6.57)$. Uczestnicy mieli w większości wykształcenie średnie (46\%) lub wyższe (34\%), podstawowe (14\%), brak danych (6\%). W drugiej części uczestniczyło 70 osób incydentalnie wybranych z grupy opisanej powyżej (w tym 48 kobiet); przeprowadzono z nimi wywiad dotyczący bilansu życia. Średnia wieku dla tej grupy wyniosła: $M=68.60 ; S D=7.64$ (kobiety, 
$n=48: M=68.97 ; S D=8.18$; mężczyźni, $n=22: M=67.77 ; S D=6.41)$. Badania były prowadzone indywidualnie od grudnia 2014 roku do kwietnia 2015 roku.

\section{METODY}

Kwestionariusz Postaw Życiowych (KPŻ) Life Attitiude Profile-Revised (LAP-R) Rekera (1992) - w polskiej adaptacji Klamuta (2010), obejmuje egzystencjalne funkcjonowanie człowieka w układzie sześciu skal prostych: $\mathrm{Cel}$ (C), Spójność wewnętrzna (SW), Kontrola życia (KŻ), Akceptacja śmierci (AŚ), Pustka egzystencjalna (PE), Poszukiwanie celów (PC) oraz dwóch złożonych: Osobowy sens (OS) i Równowaga postaw życiowych (RPŻ) - którą można traktować jako skalę ogólną. Kwestionariusz uważa się za jedną z metod służących do badania poczucia sensu życia. Metoda złożona jest z 48 twierdzeń, które odzwierciedlają postawy jednostki wobec życia i stanowią składowe pojęcia sensu życia definiowanego w trzech aspektach: poznawczym, emocjonalnym i motywacyjno-behawioralnym. Rzetelność kwestionariusza jest satysfakcjonująca, współczynniki zgodności wewnętrznej $\alpha$ Cronbacha są wyższe od .70 (Klamut, 2010, s. 42-44).

Kwestionariusz Dobrostanu Psychologicznego - The Ryff Scales of Psychological Well-Being (PWB) (Ryff, Singer, 2008) - został użyty w thumaczeniu Kroka (2013). Jest przeznaczony do badania tak zwanego dobrostanu psychicznego złożonego z sześciu elementów, którymi są: $A u$ tonomia, Rozwój osobisty, Cel życiowy i Samoakceptacja, odnoszące się do sfery wewnętrznej, ukierunkowane na rozwój Ja, oraz odnoszące się do sfery zewnętrznej, reprezentujące relacje ze środowiskiem zewnętrznym: Panowanie nad środowiskiem i Pozytywne relacje $z$ inny$m i$. Wymiary kwestionariusza PWB składają się na tak zwany dobrostan eudajmonistyczny, rozumiany w kategoriach posiadania i dążenia do wartościowych atrybutów. Współczynniki rzetelności $\alpha$ Cronbacha wynoszą powyżej .70, a stałości .73-.82 (Krok, 2013).

Wywiad Bilans Życia (WBŻ) - to częściowo ustrukturalizowany wywiad opracowany przez autorów tego artykułu, a wzorowany na wywiadzie historii życia - The Life Story Interview (McAdams, 1995). WBŻ zawiera 13 otwartych pytań dotyczących historii życia osoby badanej. Pytania uwzględniają perspektywę temporalną (przeszłość - teraźniejszość - przyszłość). $\mathrm{Z}$ uwagi na przedmiot badania wybrano tylko niektóre pytania, dodając też nowe, na przykład o doświadczenia pozytywne, trudne, przełomowe czy niosące wyzwanie. Pytano o myśli i uczucia towarzyszące najważniejszym wydarzeniom życiowym, o zmiany, jakie wywołały, oraz o ich wpływ na życie osoby. Wywiad zawierał pytania na temat najważniejszych pozytywnych oraz trudnych doświadczeń życiowych, znaczących osób i ich wpływu na życie osoby badanej, następnie pytania o przełomowe doświadczenia, życiowe inspiracje, wyzwania oraz pytania bardziej ogólne, na przykład o zmianę w myśleniu o życiu w toku lat, wartości, stosunek do życia i śmierci aż po tematy uwzględniające całościową ocenę własnego życia i jego sens. Wywiad zamyka prośba o sformułowanie czegoś na kształt przesłania dla potomnych, czyli „skryptu generatywnego" (Oleś, Puchalska-Wasyl, 2008) i ewentualne uzupełnienia.

\section{PROCEDURA}

Osoby wypełniające tylko kwestionariusze najpierw miały za zadanie uważnie przeczytać instrukcję, po czym udzielić odpowiedzi. Wyniki badanych posłużyły do analiz ilościowych (korelacje). Osoby, z którymi indywidualnie przeprowadzono wywiad, miały wyobrazić sobie swoje życie jako zapisaną księgę, po czym udzielić w miarę szczegółowych odpowiedzi na pytania dotyczące osobistej historii. Wywiad, trwający co najmniej godzinę, był nagrywany za zgodą uczestników, następnie odsłuchiwany i spisywany. Opracowanie wyników polegało na wypisaniu istotnych treści wypowiedzi i ich pokategoryzowaniu. Ponieważ nie zakładano $\mathrm{z}$ góry kategorii tematycznych, tworzono je niejako od dołu, to jest na podstawie treści wypowiedzi spisywanych w formie haseł tematycznych, a następnie redukowano określenia 
bliskoznaczne. Za pomocą tak prowadzonej analizy kategorialnej (Langdridge, 2007) wyodrębniono początkowo dziewięć kategorii: obraz siebie, wydarzenia życiowe, wartości, filozofia życia, śmierć, sens życia, cele, zmiana w życiu, ocena życia-bilans. $Z$ uwagi na podobieństwa tematyczne treści niektórych kategorii w kolejnym kroku obraz siebie włączono do kategorii ocena-bilans; wydarzenia życiowe do kategorii zmiana w życiu, a filozofia życia i cele do kategorii sens życia. W ten sposób uzyskano ostatecznie pięć kategorii: (1) ocena życia-bilans, (2) sens życia, (3) wartości, (4) śmierć, (5) zmiana w życiu.

\section{WYNIKI}

\section{Dobrostan psychologiczny a poczucie sensu życia}

Średnie wyniki w Kwestionariuszu Poczucia Sensu Życia (KPŻ) obliczone dla całej próby $(n=148)$ wskazują, iż najwyższe średnie w zakresie postaw egzystencjalnych badani uzyskali w skalach Kontrola życia $(M=41.77$; $S D=7.72)$ i Spójność wewnętrzna $(M=40.34$; $S D=7.52)$, najniższą zaś w skali Pustka egzy- stencjalna $(M=26.35 ; S D=7.01)$. Najwyższe średnie wyniki w skalach Kwestionariusza Dobrostanu Psychologicznego (PWB) uzyskano w skali Pozytywne relacje z innymi $(M=37.66$; $S D=6.67)$, a najniższe w skali Rozwój osobisty $(M=31.02 ; S D=6.58)$. Trzeba dodać, że średnie wyniki kobiet i mężczyzn w skalach obydwu kwestionariuszy nie różniły się istotnie, dlatego można było poprowadzić dalsze obliczenia dla całej grupy.

W celu odpowiedzi na pytanie, czy i jak silny związek istnieje między poczuciem sensu życia a dobrostanem psychologicznym (eudajmonistycznym poczuciem szczęścia) obliczono korelacje $r$ Pearsona pomiędzy skalami Kwestionariusza Postaw Życiowych (KPŻ) i Kwestionariusza Dobrostanu Psychologicznego (PWB). Uzyskano wiele istotnych powiązań pomiędzy skalami kwestionariuszy. Korelacje były w większości umiarkowane (zob. tabela 1).

Najmocniejsze współzależności sięgały ponad 30\% wspólnej wariancji. I tak, Cel i Sens osobowy (KPŻ) korelowały bardzo istotnie $(p<.001)$ z trzema miarami dobrostanu: $\mathrm{Pa}$ nowanie nad środowiskiem, Cel życiowy i Samoakceptacja, a Równowaga postaw życiowych (KPŻ) ze skalami: Panowanie nad środowiskiem

Tabela 1. Współczynniki korelacji $r$-Pearsona $(n=148)$ pomiędzy wynikami w skalach Kwestionariusza

\begin{tabular}{|c|c|c|c|c|c|c|c|c|}
\hline Skale PWB & $\underbrace{U}_{\vec{U}}$ & 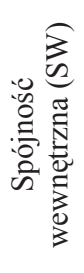 & 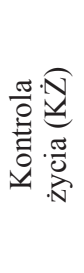 & 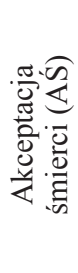 & 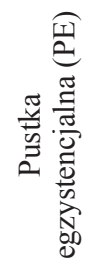 & 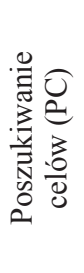 & $\begin{array}{l}30 \\
0 \\
0 \\
0 \\
0 \\
0 \\
0 \\
0 \\
0\end{array}$ & 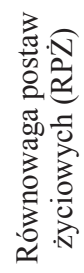 \\
\hline Autonomia & $.35^{* * *}$ & $.30^{* * *}$ & $.45^{* * *}$ & $.32^{* * *}$ &,- 14 & .05 & $.34^{* * *}$ & $.45^{* * *}$ \\
\hline Panowanie nad środowiskiem & $.55^{* * *}$ & $.51^{* * *}$ & $.54^{* * *}$ & $.31^{* * *}$ & $-.20^{*}$ & .08 & $.55^{* * *}$ & $.60^{* * *}$ \\
\hline Rozwój osobisty & $.50^{* * *}$ & $.42^{* * *}$ & $.46^{* * *}$ & $.19^{*}$ & -.07 & $.40^{* * *}$ & $.48^{* * *}$ & $.38^{* * *}$ \\
\hline Pozytywne relacje z innymi & $.50^{* * *}$ & $.44^{* * *}$ & $.47^{* * *}$ & $24^{* *}$ & -.09 & $.17^{*}$ & $.50^{* * *}$ & $.46^{* * *}$ \\
\hline Cel życiowy & $.57^{* * *}$ & $.45^{* * *}$ & $.38^{* * *}$ & .14 & $-.23^{* *}$ & $.26^{* *}$ & $.55^{* * *}$ & $.43^{* * *}$ \\
\hline Samoakceptacja & $.59^{* * *}$ & $.51^{* * *}$ & $.51^{* * *}$ & $.24^{* *}$ & $-.22^{* *}$ & .08 & $.57^{* * *}$ & $.58^{* * *}$ \\
\hline
\end{tabular}

Uwaga: $* * *$ korelacja jest istotna przy $p<.001 ; * *-p<.01 ; *-p<.05$. 
i Samoakceptacja (PWB). Korelacji bardzo istotnych $(p<.001)$, choć już nie tak wysokich, było znacznie więcej, w sumie 33 na 48 możliwych (9-30\% wariancji wspólnej). Pięć skal Kwestionariusza Postaw Życiowych miało istotne powiązania ze wszystkimi sześcioma aspektami dobrostanu psychologicznego: $\mathrm{Cel}$, Spójność wewnętrzna, Kontrola życia, Osobowy sens i Równowaga postaw życiowych. Stosunkowo najmniej powiązań ze skalami dobrostanu miały skale (z KPŻ): Pustka egzystencjalna (ujemne) i Poszukiwanie celów (po trzy istotne).

\section{BILANS ŻYCIA: ANALIZA TREŚCI}

W grupie 70 osób, z którymi przeprowadzono wywiad, przeważały osoby w wieku 60-70 lat, ścieślej osób w wieku 60-69 lat było 46 (I grupa: 32 kobiet i 14 mężczyzn), a w wieku 70-101 lat 24 osoby (II grupa: 16 kobiet i 8 mężczyzn). Pierwszy etap opracowania danych to analiza jakościowa treści wypowiedzi dotyczących bilansu życia osób z grupy młodszej (60-69 lat) i starszej (70-101 lat). Dla większej klarowności tekstu podajemy tylko po trzy przykłady (lub mniej) wypowiedzi z grupy młodszej i starszej.

Kategoria (1): ocena życia-bilans - została wyodrębniona została na podstawie odpowiedzi badanych na pytanie: W jakim stopniu Pani/ Pana życie byto/jest udane, spetnione, szczęśliwe? Większość uczestników oprócz opisowej formy: pozytywny albo negatywny, dokonała oceny w procentach; zawierały się one w przedziale $40-100 \%$. Zsumowano osoby z obydwu grup w trzech kategoriach: pozytywny bilans obejmujący taką ocenę słowną oraz oceny 75$100 \%$; bilans umiarkowanie pozytywny, czyli między 50\% a 70\%; bilans ambiwalentny lub negatywny, czyli oceny poniżej 50\% oraz ocena słowna: negatywny. W grupie osób w późnej dorosłości było nieco więcej ocen pozytywnych, a mniej negatywnych i ambiwalentnych, mianowicie bilans: pozytywny (odpowiednio: $71 \%$ i $50 \%$ ), umiarkowanie pozytywny (27\% i $29 \%$ ), oraz negatywny i ambiwalentny $(2 \%$ i $17 \%$ ).

Kategoria (2): sens życia - została wyodrębniona na podstawie następujących pytań:
Czy życie ma sens?, W czym ten sens się zawiera?, W czym Pani/ Pan odnajduje sens swojego życia? W obydwu grupach poczucie sensu życia zostało określone przez badanych jako „wysokie" (w grupie młodszej 89\% i w grupie starszej $83 \%$ badanych). Porównywane grupy podobnie cenią życie jako wartość samą w sobie (odpowiednio: 20\% i 21\%), na przykład: $\dot{Z} y c ́$ jest wartościa (m, 60). Życie jest najpiękniejszym darem $(\mathrm{k}, 61)$. W samym życiu jest sens (k, 66). Jeżeli czlowiek żyje, to znaczy, że życie ma sens (m, 73). Jakby [życie] nie miało sensu, to nie ma po co żyć (m, 74). Skoro człowiek się urodzit, to na pewno [życie] ma sens $(\mathrm{m}, 80)$. Dla poczucia sensu życia największe znaczenie ma rodzina (61\% i 50\%), na przykład: Rodzina to podstawa życia $(\mathrm{m}, 63)$. Mieć szczéśliwa rodzine to byt taki cel $w$ życiu $(\mathrm{m}, 60)$. Dzieci nadaja życiu sens $(\mathrm{m}, 62)$. [sens życia] jest $w$ rodzinie, $w$ dzieciach $i$ wnukach $(\mathrm{m}, 73)$. Jak jest dla kogo żyć to jest sens jakiś życia $(\mathrm{k}, 74)$. Dobre stosunki $i$ współdziałanie w rodzinie (m, 78). Inne aspekty życia pojawiały się znacznie rzadziej jako spontanicznie wymieniane przez badanych: otwartość na nowe doświadczenia (22\% i 13\%), na przykład: Doświadczanie, smakowanie życia $(\mathrm{k}, 66)$. Przeżyć jak najciekawiej zycie $(\mathrm{k}, 61)$. Ważne jest, żeby robić to, co sie lubi, wtedy jest jakaś satysfakcja z życia (...) Na jednym nie należy się skupiać, wszystkiego troche po trochu, urozmaicić życie... (m, 64). Potem, gdy zaczałem samodzielnie myśleć, to zrodziła się we mnie masa watpliwości (m, 75). Nie ma czegoś takiego, z czym bym sobie nie poradziła (...) każdy problem, uważałam, że jest do rozwiazania $(\mathrm{k}, 72)$. Poczucie kontroli (15\% i 8\%), na przykład: Życie ma sens, gdy nim się odpowiednio pokieruje (m, 65). [Ważne jest] osiagnięcie zamierzonego planu zyciowego $(\mathrm{m}, 78)$. Podobnie relacje $\mathrm{z}$ innymi (15\% i 8\%), na przykład: Wzajemne stosunki sa bardzo istotne, relacje $(\mathrm{k}, 65)$. Sensem sq relacje z przyjaznymi ludźmi. To, że ktoś jest mi bliski, ze ja jestem komuś bliska $(\mathrm{k}, 63)$. Trzeba być wyrozumiatym i druga osobę traktować z wielka powaga. Starać się uktadać to wspótżycie jak najbardziej pozytywnie (m, 78). Całe życie poświęciłam rodzinie $(\mathrm{k}, 72)$. O osiagnięciach, zwłaszcza w pracy i edukacji, wspomniało 
odpowiednio 7\% i 21\% badanych, na przykład: Trzeba się ksztatcić, żeby z sensem wybrać sobie jakiś zawód, żeby później całe życie się nie męczyć $(\mathrm{k}, 68)$. Zdobyć wyksztatcenie - to było bardzo ważne $w$ moim życiu (...) Bytam najszczęśliwszq osobq na świecie, jak dostałam świadectwo dojrzałości $(\mathrm{k}, 66)$. Od urodzenia, poprzez lata młodzieńcze, aż do teraz człowiek do czegoś daży i coś osiaga (...) Jak nastawimy się na ten kierunek, że życie nie ma sensu, to wtedy wszystko zaczyna się przewracać do góry nogami i nie wiadomo, do czego się daży (m, 78). Sens życia przejawia się $w$ tym, co robimy $(\mathrm{k}, 72)$. Co ciekawe, jako wartości sensotwórcze, wiarę w Boga wymieniało odpowiednio tylko 4\% i 13\%, na przykład: Cel jest $i$ to jest wspaniaty cel-wieczność. Ja ten cel znajduje, idac ta droga wskazana przez Boga $(\mathrm{k}, 75)$. Chęć pozostawienia czegoś po sobie $4 \%$ i $8 \%$, na przykład: Codziennie postępujemy tak, by nam się lepiej żyło, żeby nasze dzieci miaty lepiej $(\mathrm{m}, 61)$....dzieci i wnuki - to jest sens życia $(\mathrm{m}, 60)$. Zostawić po sobie dobra pamięć $(\mathrm{m}$, 70). ...jakiśs ślad, żeby nie zaprzepaścić istnienia, które kiedyś zostało przez kogoś zapoczatkowane $(\mathrm{m}, 79)$. Zdrowie zaś po $4 \% \mathrm{w}$ obydwu grupach, na przykład: Na pierwszym miejscu zdrowie i zdrowie najbliższych członków rodzi$n y(\mathrm{k}, 65)$. Człowiek dzisiaj zyje, wstat, jeszcze się porusza, zdrowy, może chodzić $i$ to sens jest (m, 64). W wywiadach rzadko pojawiały się dylematy związane z poszukiwaniem sensu życia (4\% i 17\%). W narracjach osób bardziej zaawansowanych wiekiem w ogóle nie pojawiło się odniesienie do piękna, podczas gdy w młodszej grupie 13\% badanych upatrywało sensu życia w jego pięknie, na przykład: Piękno tego świata mnie fascynuje $(\mathrm{k}, 68)$. Wszystko jest piękne, każdy dzień każda noc, każda chwila $w$ życiu $(\mathrm{k}, 66)$.

Jak widać, w obydwu grupach przeważają podobieństwa, a ewentualne różnice dotyczą tych aspektów życia, które były rzadko wymieniane jako nadające życiu sens.

Kategoria (3): wartości - została uzyskana na podstawie odpowiedzi na pytanie: Co jest dla Pani/Pana ważne w ocenie catego życia? W odpowiedziach badani często odnosili się do wartości. Pytania o różne życiowe doświadcze- nia, wyzwania, znaczące osoby czy inspiracje były w istocie pytaniami o wartości. Wypowiedzi zawierające odniesienia do wartości poszczególnych rodzajów były do nich kwalifikowane na podstawie analizy kategorialnej (Langdridge, 2007). W celu określenia, jakie wartości są ważne, a jakie mniej lub zupełnie nieistotne w bilansie życia osób badanych, posłużono się listą wartości z kołowego modelu Schwartza (za: Cieciuch, 2013). W tym przypadku analizę kategorialną prowadzono na zasadzie przypisywania wypowiedzi na podstawie ich treści do z góry określonych kategorii. W treści wypowiedzi badanych identyfikowano wartości z modelu Schwartza; następnie zgodnie ze strukturą tego modelu podzielono je na cztery grupy: otwartość na zmianę versus zachowawczość oraz umacniania siebie versus przekraczanie siebie.

Otwartość na zmianę jest reprezentowana przez kierowanie sobą w myśleniu (70\% i 42\%) i w działaniu (po 67\%) oraz przez stymulację (28\% i 13\%), na przykład: Być otwartym na świat, czytać, myśleć, przede wszystkim myśleć (k, 61). Trzeba tak żyć, żeby być wolnym człowiekiem (m, 64). Ważne (...) by żyć zgodnie ze swoimi wartościami $(\mathrm{k}, 69)$. Ważne w życiu, by zyć zgodnie z zasadami swoimi $(\mathrm{k}, 77)$. Wszyscy mnie namawiali do wstapienia do partii $i$ sugerowali $w$ ten sposób, że jak nie zapiszę się do partii, to nie będę w ogóle miała szans awansu. A ja powiedziałam, że mnie w ogóle na awansie nie zależy, mnie zależy na pracy $(\mathrm{k}, 73)$. Należy obrać kierunek ten, który ja uważam za najlepszy, który ja chciałam osiagnać (...), żeby być zadowolona i żeby ze mnie byli zadowoleni przełożeni $(\mathrm{k}, 91)$.

Zachowawczość obejmuje bezpieczeństwo osobiste (61\% i 54\%) i społeczne (po 4\%), przystosowanie do reguł $(28 \%$ i $17 \%)$ i do ludzi (54\% i 42\%) oraz tradycję (52\% i 67\%), na przykład: Zawsze trzeba się odnosić do innych i patrzeć na innego i nie mierzyć własna miara (k, 60). Lepiej być biedniejszym, a uczciwym $i$ wobec Boga, $i$ wobec ludzi $(\mathrm{m}, 66)$. Tak żyć, by ktoś mógł na mnie liczyć. By nikt się nie zawiódt (k, 67). Trzeba się modlić, do kościoła chodzić, być wierzacym (k, 70). Szacunek do siebie i do ludzi (m, 71). Nie szkodzić innym 
(m, 80). Umacnianie siebie zawiera: hedonizm (26\% i 13\%), osiagnnięcia (67\% i 100\%), władze ( $0 \%$ i $4 \%$ ) oraz prestiż (26\% i 54\%), na przykład: Wszystkiego trzeba pokosztować $(\mathrm{k}, 60)$. [Sens] Jest pewnym osiagnięciem zamierzonego planu życiowego $(\mathrm{k}, 61)$. Wszędzie, gdzie chciałam pojechać, pojechałam (k 71). Uświadomiłem sobie, że jak chce, to potrafie, potrafitam. Uczytem sie sam, przy pomocy ksiażek, od podstaw (m, 77).

Natomiast przekraczanie siebie obejmuje: troskliwość (obie grupy po 100\%), niezawodność wobec innych (28\% i 25\%) oraz uniwersalizm społeczny, czyli dążenie do równości, sprawiedliwości i dobra wszystkich ludzi (13\% i 29\%), ekologiczny wyrażający się ochroną środowiska naturalnego (9\% i 13\%) oraz tolerancję (30\% i 17\%). W tej kategorii przykłady trafnie oddają (meta)refleksję charakterystyczną dla okresu integracji: Ważna jest miłość do ludzi i świata $(\mathrm{k}, 65)$. Najważniejsze jest zdrowie $i$ szacunek dla ludzi $(\mathrm{m}, 68)$. To jest chyba najważniejsze, żeby człowiek umiał rozmawiać $z$ drugim człowiekiem (...) przede wszystkim nie robić nikomu krzywdy (k, 67). Żeby wzajemne zrozumienie się ludzi było. Żeby człowiek człowiekowi byt przyjacielem. Żeby pieniadz nie dzielit ludzi. Trzeba się kochać, zbliżać do siebie, a nie oddalać (m, 73). ...żeby ze soba nie walczyli. Żeby nie było wojen, żeby ludzie nie ginęli $w$ sposób głupi. (...) Człowiek jest jednostka społeczna (m, 79). Żeby wszyscy żyli w zgodzie, w miłości, w jedności $(\mathrm{k}, 83)$.

Kategoria (4): śmierć - została wyodrębniona na podstawie pytania: Jaki jest Pani/ Pana stosunek do śmierci? Śmierć - rozumiana jako naturalny element życia występuje w narracjach ponad połowy uczestników badania (52\% i $63 \%$ ), podobnie jak postawa akceptacji i oswojenia się ze śmiercią ( $54 \%$ i 67\%): W miare przeżywania kolejnych lat oswajam się z ta myśla. Im masz więcej lat, tym częściej się w myślach ten watek pojawia, bo człowiek sobie zdaje sprawę, że ta wycieczka dobiega końca $(\mathrm{m}, 60)$. Śmierć to nie jest nic złego, co mogłam, to spetniłam, teraz moge swobodnie umrzeć. Jestem spokojna, każdego dnia jestem przygotowana (k, 64). W tej chwili to dla mnie może przyjść $i$ dzisiaj. Ja się tego $w$ ogóle nie boje $(\mathrm{k}, 75)$. Śmierć to jest jedyna prawda na świecie. Ja jej się nie boje (m, 80). Chcę, żeby szybko przyszła. Co to za zycie teraz... $(\mathrm{k}, 101)$.

Rozważania dotyczące śmierci w duchu religii chrześcijańskiej ujawnia jedna czwarta badanych (28\% i 25\%), na przykład: Jestem spokojna, bo każdy dzień jestem przygotowana. Jest wieczne życie $(\mathrm{k}, 64)$. Śmierć to jest przejście do lepszego życia $(\mathrm{k}, 75)$. W obu grupach badanych w równym stopniu pojawia się myślenie o własnej śmierci teraz (54\%) i w przeszłości (22\% i 21\%), na przykład: Stosunek do śmierci zmienia się, teraz jest to dla mnie bardziej realne $(\mathrm{k}, 61)$. Człowiek się z tym oswaja i uświadamia sobie przemijanie. Jak człowiek ma $18 \mathrm{czy} 20$ to eee tam. A jak ma 50 i obok ciebie ludzie znikaja, to oswaja się z tym $i$ do świadomości dociera, że my tu wpadliśmy na chwilę $(\mathrm{m}, 60)$. [W młodości o śmierci myśli się z] jakimś takim strachem, z jakaśs obawa, dla mnie to było zupetnie coś innego, taka abstrakcja, czy coś takiego (...) A teraz jakoś spokojniej, spokojniej, absolutnie, bez jakiś obaw, bez żadnego strachu $(\mathrm{k}, 65)$. Wcześniej nie myślało się o śmierci, bo to praca, to dzieci... (k, 75). Jak człowiek byt młodszy, to może sobie troche o śmierci myślat. Jakiś tam strach byt. Sobie wyobrażat, w jaki sposób umrze. Teraz, jak człowiek jest $w$ wieku starszym, to jakoś tak obojętnie o tym myśli. Wie, że to już niedtugo będzie. Ale nie myśle o tym i nie przeżywam $(\mathrm{k}, 71)$. Kiedyś, jak byłam młoda, to w ogóle nie myślałam o śmierci. Starszy umart, to umart, ale że ja będę umierać...? Teraz to już wiem, że trzeba umrzeć i mnie. Jak się postarzałam, to zaczęłam tak myśleć $(\mathrm{k}, 83)$. Wspomnienia śmierci bliskich osób (po 46\% w obydwu grupach) reprezentują wypowiedzi: Śmierć najbliższych, to właśnie przede wszystkim byto takie stresujace $(\mathrm{k}, 65)$. To sq te tragiczne sytuacje. (...) Czasami człowiek usiqdzie i to wszystko sie przypomina. Zostaje to w podświadomości (m, 61). Wcześniej się bałem śmierci, strasznie się batem tego wszystkiego. Trzymatem ojca za rękę jak on umierat, po tym to się zmieniło $(\mathrm{m}, 62)$. Pierwsze lata to byt straszny szok (k, 77). Z mężem przeżyłam 52 lata i byliśmy bardzo szczęśliwi. Ale przychodzi ten pewien wiek i człowiek dziękuje Bogu, że odszedt lekko, że nie cierpiat 
i nie leżat (k, 77). To sq takie sytuacje bardzo trudne. Tyle lat minęto i człowiek tego nie zapomina (m, 79). Kwestię obecnie odczuwanego lęku przed śmiercią porusza zaledwie po kilka procent uczestników (3\% i 8\%), na przykład: Lęk przed śmierciq zawsze jest i taka pokora (m, 61). Zawsze staram się odsuwać od siebie te myśli $(\mathrm{k}, 65)$. Śmierci się boję, że pójdę do piekła, że będzie mi tam bardzo źle. Tego się boję. Tego wszyscy się boja. Jeśli ludzie byliby przekonani, że tam będzie lepiej, nie baliby się. A większość ludzi się boi. Czyli ta wiara jest taka sobie... (k, 69). Nie boję się śmierci. To jest rzecz normalna i każdego ona czeka $(\mathrm{k}, 77)$. Często myślę o śmierci (...), nie ma raczej lęku przed śmiercia $(\mathrm{k}, 85)$. Chcę, żeby szybko przyszła. Co to za życie teraz? $(\mathrm{k}, 101)$. Porównywalnie rzadko pojawiał się lęk przed śmiercią w myślach w przeszłości (11\% i 8\%). Dwukrotnie więcej osób obawia się bycia ciężarem dla innych $(20 \%$ i 17\%), na przykład: Myśle tylko, żeby nie być ciężarem dla rodziny $(\mathrm{k}, 63)$. Najlepiej to by było nie chorować, nie leżeć w tóżku i nie być obciażeniem dla swoich dzieci (m, 78), stąd też pragnienie ,szybkiej” lub „lekkiej” śmierci (7\% i 17\%), na przykład: Nie zazdroszczę nikomu dożywania tak zwanego późnego wieku, jeżeli z tym sie nie taczy petna sprawność fizyczna i psychiczna - tutaj nie ma sensu bić rekordów. Jeżeli umrzeć, to zasnać, nie cierpieć i nie być kłopotem dla nikogo $(\mathrm{k}, 61)$....jak ktoś się połozyt spać i nie wstat $w$ dniu następnym, to myśle sobie, że to wspaniała, cudowna śmierć $(\mathrm{k}, 61)$. Niektórzy maja szczęście właśnie - umierać tak jak drzewa-stojac $(\mathrm{k}, 61)$. Najlepiej to by byto nie chorować, nie leżeć w tóżku i nie być obciqżeniem dla swoich dzieci (m, 78). Mam tylko takie pragnienie, żeby do tego doszło w sposób naturalny (m, 79). Nagła śmierć jest dobra. Jest dobra dla wszystkich i dla umierajacego i dla otoczenia $(\mathrm{m}, 80)$.

Kategoria (5): zmiana - składały się na nią głównie odpowiedzi na następujące pytania: Czy coś (...) się zmieniło? Czy i jak zmienito Pania/Pana? Czy $i$ w jaki sposób wptynęto na Pani/Pana życie? Czy wptynęło na relacje z innymi, zmiane zainteresowań, prace, inna zmianę? Najwięcej zmian badani relacjonowali w wyniku różnych doświadczeń życio- wych: trudnych (76\% i 79\%), pozytywnych (70\% i 83\%), przełomowych (61\% i 50\%), o charakterze wyzwania (72\% i 54\%), kontaktu ze znaczącymi osobami (83\% i 67\%). Interpretacja doświadczeń, które prowadziły do zmian oraz reinterpretacja ich sensu w życiu człowieka wydaje się jednym z węzłowych wyzwań okresu starości, dlatego podamy po pięć przykładów wypowiedzi, na przykład: $S a$ momenty załamania, które by mnie pograżyly, gdybym się poddat. Trzeba temu zapobiec. To jest silna wola: trzeba wstać, trzeba iść - tak sobie myślę $(\mathrm{m}, 68)$. Zyskałam wewnętrzna sitę $(\mathrm{k}, 60)$. Nauczyłam się pokory (...) wyrozumiałości $i$ wypośrodkowania $(\mathrm{k}, 66)$....nauczyło [życie] żeby zbyt pochopnie nie oceniać innych $(\mathrm{k}, 61)$. Nauczytam się odpowiedzialności (k, 62). Duży wpływ na moje życie miała moja starsza koleżanka, która pomogła mi uwierzyć $w$ siebie i osiagnać $w \dot{z} y c i u$ to, co miało być dla mnie osiagalne $(\mathrm{k}, 72)$. Dyrektor byt porzadnym człowiekiem. Byt dla mnie wzorem. Nauczytem się od niego podejścia do ludzi (...), żeby być człowiekiem prostolinijnym, uczciwym, prawdomównym, bez oszukaństwa, krętactw $i$ tego też wymagać od innych. Od rodziców nauczytem się kochać Boga, co to znaczy więź rodzinna, miłości $i$ tego, że należy pomagać jeden drugiemu (m, 74). Nasz ojciec też nam mówił zawsze: „Lepiej dać, niż brać”. Człowiek nie patrzy, żeby sobie zagarnać, ale jak ma, to lepiej podzieli się z kimś. To jest większa satysfakcja $(\mathrm{k}, 78)$. [Ksiqdz] wpoit w nas dużo dobrych zasad: jak szanować innych ludzi, jak zachować się $w$ sytuacjach trudnych, jak wyzwalać energię, by nie czekać, aż ktoś pomoże, a sobie samemu pomóc (m, 79). [po wojnie] Zrobiłem się też bardzo szorstki w stosunku do życia (m, 80).

Ostatni etap analiz polegał na porównaniu osób z pozytywnym bilansem (według ich ocen) z osobami, których bilans był ambiwalentny lub negatywny (zob. kategoria 1). Wyodrębniono dwie grupy: grupa ,pozytywny bilans”, to 37 osób (w tym 24 kobiety), które uznały swoje życie za udane w $80-100 \%$, plus te, które uznały je za pozytywne bez podania procentów. Grupa „ambiwalentny lub negatywny bilans”, to 31 osób (w tym 23 kobiety), które uznały 
swoje życie za udane w 40-75\%, plus te, które uznały je za nieudane bez podania procentów (dwie osoby nie udzieliły odpowiedzi na to pytanie). W celu sprawdzenia, czy występują istotne różnice między średnimi wynikami uzyskanymi w skalach kwestionariuszy KPŻ i PWB przez obydwie grupy, przeprowadzono analizę testem $t$-Studenta (tabela 2).

W skalach dobrostanu psychologicznego wystąpiły dwie istotne różnice. Uczestnicy z grupy o pozytywnym bilansie uzyskali istotnie wyższe wyniki w skalach dobrostanu: Panowanie nad środowiskiem oraz Rozwój osobisty, co sugeruje większą skuteczność w radzeniu sobie z otaczającym światem oraz wyższy poziom osobowościowej dojrzałości. W Kwestionariuszu Postaw Życiowych (KPŻ) nie wystapiły istotne różnice między grupami.

\section{DYSKUSJA WYNIKÓW}

Uzyskane wyniki badań ilościowych wskazują na istnienie wyraźnych związków postaw egzystencjalnych z miarami dobrostanu psychologicznego (Ryff, 2014). Oznacza to, że hipoteza postulująca związek poczucia sensu życia z dobrostanem psychologicznym została potwierdzona, nie uzyskano jednak wysokich korelacji, lecz jedynie umiarkowane i niskie. Ogólnie im wyższy poziom dobrostanu, tym wyższy poziom postaw egzystencjalnych, $\mathrm{z}$ wyjątkiem Pustki egzystencjalnej (tu korelacje ujemne i nie wszystkie istotne) oraz Poszukiwanie celów (istotne korelacje tylko z Rozwojem osobistym i Celem życiowym, $p<.01$ ). Umiarkowanie silną dodatnią współzależność stwierdzono między poczuciem sensu życia

Tabela 2. Porównanie średnich wyników osób, które uznały swoje życie za udane i umiarkowanie udane, w skalach kwestionariuszy KPŻ i PWB

\begin{tabular}{|l|c|c|c|c|c|c|c|}
\hline \multirow{2}{*}{ Skala } & \multicolumn{2}{|c|}{$\begin{array}{c}\text { Bilans } \\
(n=37)\end{array}$} & \multicolumn{2}{c|}{$\begin{array}{c}\text { Bilans }+/- \\
(n=31)\end{array}$} & \multicolumn{3}{c|}{ Istotność różnic } \\
\hline PWB & $\mathrm{M}$ & $\mathrm{SD}$ & $\mathrm{M}$ & $\mathrm{SD}$ & $\mathrm{t}$ & $\mathrm{p} \leq$ & $\mathrm{d}$ Cohena \\
\hline Autonomia & 36.27 & 5.98 & 34.27 & 4.49 & 1.56 & .122 & .373 \\
\hline Panowanie nad środowiskiem & 36.78 & 5.56 & 33.93 & 4.76 & 2.22 & .030 & .546 \\
\hline Rozwój osobisty & 32.43 & 5.41 & 29.30 & 6.28 & 2.19 & .032 & .539 \\
\hline Pozytywne relacje z innymi & 39.46 & 3.73 & 37.23 & 5.44 & 1.91 & .062 & .487 \\
\hline Cel życiowy & 33.76 & 5.47 & 31.93 & 6.20 & 1.28 & .206 & .314 \\
\hline Samoakceptacja & 33.22 & 5.00 & 31.50 & 4.11 & 1.52 & .136 & .371 \\
\hline KPŻ & & & & & & & .219 \\
\hline Cel ( C) & 39.86 & 7.63 & 37.53 & 7.68 & 1.24 & .305 \\
\hline Spójność wewnętrzna & 42.00 & 5.92 & 39.13 & 6.88 & 1.83 & .071 & .450 \\
\hline Kontrola życia & 43.11 & 6.38 & 41.93 & 6.11 & 0.76 & .448 & .188 \\
\hline Akceptacja śmierci (AŚ) & 38.68 & 9.06 & 35.47 & 10.24 & 1.36 & .179 & .334 \\
\hline Pustka egzystencjalna (PE) & 25.54 & 5.81 & 27.30 & 7.28 & -1.10 & .275 & .270 \\
\hline Poszukiwanie celów (PC) & 32.49 & 7.57 & 32.17 & 8.40 & .16 & .870 & .040 \\
\hline Sens osobowy (OS) & 81.86 & 12.71 & 76.67 & 13.49 & 1.62 & .110 & .398 \\
\hline Równowaga postaw (RPŻ) & 10.62 & 27.32 & 94.60 & 21.96 & 1.79 & .078 & .440 \\
\hline
\end{tabular}


a samoakceptacja; pozytywne nastawienie do siebie łączy się z poczuciem osobowego sensu. Nie wykryto przy tym istotnych różnic między średnimi wynikami kobiet i mężczyzn w obydwóch kwestionariuszach.

Różnice w zakresie poczucia sensu życia oraz dobrostanu psychologicznego między osobami, które w ramach wywiadu relacjonowały pozytywny i negatywny lub ambiwalentny bilans życia, okazały się niewielkie. Dotyczyły one jedynie Panowania nad środowiskiem (PWB) i Pustki egzystencjalnej oraz Osobowego sensu (KPŻ). Badani, którzy wysoko oceniali swoją egzystencję (w wywiadzie), uzyskali jednocześnie wyższe wyniki w zakresie radzenia sobie w środowisku oraz w niektórych aspektach postaw egzystencjalnych. Badani, którzy względnie nisko ocenili swoje życie w wywiadzie, osiagnęli wyniki świadczące o frustracji egzystencjalnej i mniej skutecznym radzeniu sobie w znaczeniu panowania nad środowiskiem. W większości skal różnice nie były istotne. O ile różnice między tymi grupami nie dziwią, o tyle brak różnic wydaje się zaskakujący. Jak to możliwe, że osoby w pełni zadowolone z życia i zadowolone jedynie umiarkowanie lub ambiwalentne różnią się tylko $\mathrm{w}$ trzech miarach na 14 możliwych w zakresie poczucia sensu życia i dobrostanu psychologicznego? Uzyskany wynik jest tym bardziej zadziwiający, że Brudek (2017) uzyskał umiarkowaną i względnie wysoką korelację między satysfakcją z życia mierzoną skalą Dienera a (pozytywnym) bilansem życia $(r=0,65)$. Stwierdził ponadto, że pozytywny bilans życia pełni funkcję mediatora w związku między neurotycznością a satysfakcją z życia.

Stosunkowo niewielkie różnice w subiektywnej ocenie dobrostanu psychologicznego i nasileniu postaw egzystencjalnych wśród naszych badanych można uznać za wynik kontrintuicyjny, zwłaszcza w świetle teorii głoszącej, iż integracja psychiczna łączy w sobie pozytywny bilans z poczuciem sensu życia i wysokąjakością psychologicznego funkcjonowania, charakterystyczną dla osiagniętej dojrzałości (Erikson, 2002). Co ciekawe, analogiczny rezultat uzyskali Brudek i Steuden (2016), porównując osoby starsze $\mathrm{z}$ pozytywnym i nega- tywnym bilansem pod kątem stylów radzenia sobie ze stresem i nadziei na sukces. Obydwa wyniki można wyjaśniać dystansem do siebie i rzeczywistości uzyskanym w ramach tak zwanej gerotranscendencji, która oznacza obniżenie egocentryzmu i filozofię życia opartą na wartościach duchowych i społecznych, spojrzenie na życie niejako ponad własną historią i interesem (Tornstam, 1999; Straś-Romanowska, 2011).

Trzeba też zauważyć, że stopień zadowolenia z życia wyrażający się całościowym bilansem oraz miary dobrostanu i postaw egzystencjalnych to jednak dość różne rzeczy. Po pierwsze, bilans odnosi się głównie do przeszłości, a kwestionariusze mierzą raczej aktualne funkcjonowanie. Po drugie, ambiwalentny bilans może być funkcją raczej refleksyjności (im większa refleksyjność, tym mniej jednoznaczna ocena całościowa) niż wynikiem trudności w osiąganiu wartościowych celów czy problemów egzystencjalnych. Podsumowując, związek między postawami egzystencjalnymi i psychologicznym dobrostanem a całościowym bilansem życia okazał się słaby.

Analiza treści narracji pod kątem pięciu kategorii: (1) ocena-bilans życia, (2) sens życia, (3) wartości, (4) śmierć (5) zmiana w życiu, przynosi odpowiedź na otwarte pytanie badawcze. W wypowiedziach badanych stosunkowo słabo wybrzmiały problemy zdrowotne i związana z nimi obniżona jakość psychospołecznego funkcjonowania, potwierdzona $\mathrm{w}$ innych badaniach (Mirucka, Bielecka, Kisielewska, 2017). Problemy z samooceną też nie były akcentowane przez uczestników badania, co częściowo mogło wynikać z treści pytań.

Kategoria ocena-bilans życia jest ważna dlatego, że zawiera całościową ocenę życia. Wyniki okazały się w tym sensie optymistyczne, że zdecydowana większość badanych oceniła swoje życie pozytywnie lub zdecydowanie pozytywnie. Może to odpowiadać integracji jako etapowi rozwoju (Erikson, 2002). Badani wiązali zadowolenie $\mathrm{z}$ życia $\mathrm{z}$ autonomią $\mathrm{w}$ myśleniu i działaniu, kontrolą swojego życia oraz możliwością kształtowania środowiska. Z pozytywnym bilansem łączyło się przekonanie, że w swojej obecnej sytuacji badani nie dokonywaliby zmian. Rezultat taki można interpretować 
w kategoriach postrzeganego poczucia ciagłości w życiu, tego, że kolejne fazy życia są ze sobą spójne (McAdams, Josselson, Lieblich, 2002) - a to świadczy o przystosowaniu do starości (Susułowska, 1989; Steuden, 2011).

Podobnie wnioski dotyczące kategorii sens życia pokazują że większość osób, które udzieliły wywiadu, uznała, że życie ma sens. Ponad połowa z nich, w tym głównie kobiety, potwierdziła, że rodzina w największym stopniu czyni życie sensownym i wartościowym.

Najbardziej znaczącymi wartościami (kategoria wartości) w życiu osób okazały się: (1) troska o dobro bliskich osób, czyli życzliwość-troskliwość, (2) osiagnięcia oraz (3) kierowanie sobq $w$ działaniu, czyli niezależność w podejmowaniu decyzji i wolność w wyborze działań i realizowaniu celów. Według Susułowskiej (1989) sukcesy w pracy zawodowej (mężczyzn i samotnych kobiet) oraz uczucie, że jest się potrzebnym - to jedne $\mathrm{z}$ najbardziej istotnych kwestii składających się na pozytywny bilans życia. Oprócz powyższych wartości ważne dla prawie połowy badanych okazały się także: kierowanie soba w myśleniu, tradycja i bezpieczeństwo osobiste. Nastapiło przesunięcie preferencji w kierunku wartości społecznych, moralnych i religijnych, zgodnie ze wspomnianym już modelem gerotranscendencji (Tornstam, 1999; Straś-Romanowska, 2011).

Problem śmierci (kategoria śmierć), jak również postaw wobec niej, należał do ważnych tematów w wypowiedziach osób udzielających wywiadu. Ponad połowa badanych śmierć pojmowała jako naturalny element życia. Jak pisze Straś-Romanowska (2011), „Starsi ludzie na ogół nie odczuwają tak silnego lęku jak młodzi, zdążyli się już bowiem oswoić z myślą o nieuchronności śmierci, nie są jednak od niego wolni" (s. 346). Wypowiedzi dotyczące śmierci wskazują na jej afirmację, co można przyjąć za znak dojrzałości psychologicznej badanych, integracja w kategoriach Eriksona (2002), właściwe przygotowanie się do finału (spełnionego) życia według Junga (1971) czy też godne starzenie się według Steuden (2011).

Pozytywnej ocenie życia towarzyszyła zazwyczaj postawa akceptacji śmierci, a lęk przed śmiercią, charakteryzujący jedną piątą bada- nych, występował najczęściej u osób o niezbyt pozytywnym bilansie. Mniejszy lęk wobec śmierci - jak twierdzą Izdebski, Jurga i Kosiol (2012) - wiąże się z większym stopniem zrozumienia i akceptacji śmierci oraz większym dystansem wobec niej, tym samym więc wpływa na dodatni znak bilansu życiowego. Warto dodać, że obawa przed śmiercią dotyczyła głównie możliwości doznawania bólu, cierpienia oraz bycia dla innych ciężarem, a także wiązała się z ,nieznanym”, czyli pytaniem, co następuje po niej.

Istotnym tematem $\mathrm{w}$ treściach wywiadów była kwestia zmiany w życiu. Zmiany dotyczyły myślenia o sobie, świecie i innych ludziach, były wynikiem wielorakich doświadczeń, zarówno pozytywnych, jak i trudnych, relacji ze znaczącymi osobami, rozmaitych inspiracji, w tym mądrości innych lub zasłyszanych historii - co wskazuje na czerpanie pozytywnych wzorców w rozwoju osobowości (McAdams, Josselson, Lieblich, 2002). Niektóre zmiany wynikały z osobistych przewartościowań. Zjawiska związane ze zmianami i ich wpływem na bieg życia oraz postawy życiowe obrazuja procesy selektywnej optymalizacji i kompensacji (Baltes, Baltes, 1990), czyli koncentracji na subiektywnie ważnych sferach aktywności, a także kontroli wtórnej (Heckhausen, 1999), czyli konieczności kontrolowanego ograniczenia niektórych form aktywności.

Badania empiryczne skupiające się na składnikach dobrostanu ujawniaja, iż dobrze przeżyte, udane życie to nie tylko brak trudnych doświadczeń i emocji, ale przede wszystkim sposób, w jaki radzimy sobie z wyzwaniami i trudnościami i jakie znaczenie im przypisujemy (Ryff, Singer, za: Czapiński, 2004, s. 156). Wyznacznikiem życia udanego, spełnionego osób badanych nie była potrzeba zmiany przeszłych doświadczeń, lecz raczej adekwatna do okresu życia zmiana priorytetów oraz własnego nastawienia do siebie, obecnej sytuacji oraz stosunku do przeszłości (por. Steuden, 2011). Osoby, które w globalnej ocenie uznały swoje życie za mniej satysfakcjonujące, częściej mówiły o potrzebie zmiany w kontekście niezrealizowanych marzeń i niespełnionych celów. Susułowska (1989) wskazuje, iż ,poczucie niespełnionych marzeń, 
wielkich nadziei i oczekiwań" (s. 320) mieli na ogół wszyscy badani, co wynika z prostego faktu, że realizacja marzeń jest zazwyczaj jedynie częściowa. Co więcej, dopiero z perspektywy czasu ludzie mogą ocenić, co w ich życiu było wartościowe i godne starań. Kępiński (1977) natomiast traktował rozdźwięk między ,planem” a ,wykonaniem” w kontekście całościowego bilansu życia jako rezultat pojawiających się w starości takich uczuć, jak lęk, przygnębienie czy poczucie winy.

Jak wykazały Cierpka, Dryll i Tokarska (2017), z wyższym poczuciem jakości życia i pozytywnym bilansem łączy się przekaz mądrościowy adresowany do młodego pokolenia (list do wnuka) jako szczególny przejaw generatywności i integracji.

Susułowska (1989) w swoich badaniach zwróciła uwagę na potrzebę samorealizacji jako istotnego wyznacznika bilansu życia. Poczucie niespełnienia w późnym okresie życia sugeruje, że potrzeby traktowane jako mało ważne lub słabo uświadamiane we wcześniejszych okresach życia zostały z perspektywy czasu ocenione jako ważne i mające wpływ na globalna ocenę egzystencji.

Podsumowując, psychologiczny dobrostan i postawy egzystencjalne to względnie niezależne wymiary wobec bilansu życia. Poczucie sensu własnej egzystencji oraz dobrostan psychologiczny korelują na poziomie umiarkowa- nym, dlatego w celu poznania psychologicznej kondycji (przystosowania) w okresie starości trzeba badać i jedno, i drugie. Jednocześnie ani sens, ani dobrostan, ani nawet obydwa razem wzięte nie przesądzają o bilansie życia. Pytanie, w jakim stopniu życie było udane, nawiązuje do myślenia narracyjnego (Bruner, 1990), stąd odpowiedź nie jest logicznym wnioskiem wyprowadzonym z poczucia sensu i poziomu dobrostanu, ale stanowi unikatowe podsumowanie osobistej historii (McAdams, Josselson, Lieblich, 2002).

Ograniczeniem badań jest dobór osób badanych: po pierwsze, nie wszyscy zapytani wyrazili zgodę na badanie, po drugie, zamieszkiwali północno-wschodnią część naszego kraju, nie są wiec reprezentatywni dla całej populacji. Kolejnym ograniczeniem był kwestionariuszowy charakter części badań, a jak wiadomo, w badaniach kwestionariuszowych wartość wypowiedzi jest częściowo pochodną zadanych pytań, zdolności do refleksji uczestników badania oraz ich nastawienia (np. kwestia aprobaty społecznej). Cenny natomiast jest materiał jakościowy ujawniający sposób myślenia osób starszych na temat ich życia i jego wartości. Niektóre wypowiedzi mają charakter mądrościowy (Baltes, Baltes, 1990), okres młodości charakteryzuje się bowiem myśleniem o przeszłości, dążeniem do stabilizacji, czerpaniem radości z tego, co jest i co się kiedyś osiągnęło.

\section{BIBLIOGRAFIA}

Adler A. (1986), Sens życia. Warszawa: Wydawnictwo Naukowe PWN.

Baltes P.B., Baltes M.M. (1990), Successful Ageing: Perspectives from the Behavioral Sciences. New York: Cambridge University Press.

Brudek P. (2017), Mediacyjna rola bilansu życiowego w związkach cech osobowości i satysfakcji z życia osób starszych. Gerontologia Polska, 3(25), 168-175.

Brudek P., Steuden S. (2016), Style radzenia sobie ze stresem, samoocena i nadzieja na sukces u osób w okresie późnej dorosłości o odmiennej specyfice bilansu życiowego. Psychoterapia, 1 (176), s. 87-102.

Bruner J. (1990), Acts of Meaning. Cambridge: Harvard University Press.

Bühler Ch. (1999), Bieg życia ludzkiego z perspektywy psychologicznej. Warszawa: Wydawnictwo Naukowe PWN.

Butler R. (1963), The life review: On interpretation of reminiscence in the aged. Psychiatry, 1, 65-76.

Cieciuch J. (2013), Ksztaltowanie się systemu wartości od dzieciństwa do wczesnej dorostości. Warszawa: Wydawnictwo Liberi Libri.

Cierpka A., Dryll E., Tokarska U. (2017), Poczucie jakości życia w okresie starości a przekaz doświadczenia życiowego. W: B. Bartosz, E. Dryll, J. Klebaniuk (red.), Jakość życia w refleksji psychologicznej wedtug uczniów i przyjaciół Marii M. Straś-Romanowskiej (s. 141-159). Warszawa: Eneteia Wydawnictwo Szkolenia. 
Czapiński J. (2004), Psychologia pozytywna. Nauka o szczęściu, zdrowiu i cnotach człowieka. Warszawa: Wydawnictwo Naukowe PWN.

Erikson E.H. (2002), Dopetniony cykl życia. Poznań: Dom Wydawniczy REBIS.

Heckhausen J. (1999). Developmental Regulation in Adulthood. Age-normative and Sociostructural Constrains as Adaptive Challenges. Cambridge: Cambridge University Press.

Izdebski P., Jurga M., Kosiol M. (2012), Bilans życiowy a postawa wobec śmierci w późnej dorosłości. Gerontologia Polska, 20, 155-159.

Jung C.G. (1971), The stages of life. W: J. Campbell (red.), The Portable Jung (s. 3-22). New York: Penguin. Kępiński A. (1977), Lęk. Warszawa: Państwowy Zakład Wydawnictw Lekarskich.

Klamut R. (2010), Kwestionariusz Postaw Życiowych KPŻ. Podręcznik do polskiej adaptacji kwestionariusz Life Attitude Profile - Revised (LAP-R) Gary'ego T. Rekera. Warszawa: Pracownia Testów Psychologicznych PTP.

Krok D. (2013), Nadzieja jako predyktor wymiarów dobrostanu psychicznego. Polskie Forum Psychologiczne, $18,157-172$.

Langdridge D. (2007), Phenomenological Psychology. Theory, Research and Method. Harlow: Pearson: Education Limited.

Maslow A. (1986), W strone psychologii istnienia. Warszawa: Instytut Wydawniczy PAX.

McAdams D.P. (1995), The life story interview, http:/www.sesp.northwestern.edu/foley/instruments/interview (revised 1995).

McAdams D.P., Josselson R., Lieblich A. (2002), Turns in the Road. Narrative Studies of Life in Transition. Washington: American Psychological Association.

Mirucka B., Bielecka U., Kisielewska M, (2017), Znaczenie wieku realnego i wieku subiektywnego w doświadczanie siebie cielesnego przez osoby w wieku senioralnym. Polskie Forum Psychologiczne, 22, 159-175.

Obuchowski K. (2000), Galaktyka potrzeb. Psychologia dażeń ludzkich. Warszawa: Wydawnictwo Zysk i S-ka. Oleś P.K. (2012), Psychologia czlowieka dorosłego. Warszawa: Wydawnictwo Naukowe PWN.

Oleś P.K., Puchalska-Wasyl M. (2008), Teoria narracyjnej tożsamości Dana P. McAdamsa. W: A. Batory, P.K. Oleś (red.), Tożsamość i jej przemiany a kultura. Lublin: Wydawnictwo KUL.

Reker G.T. (1992), Life Attitude Profile - Revised (LAP-R). Manual. Peterborough, Ontario: Students Psychologist Press.

Reker G.T., Chamberlain K. (2000), Introduction. W: G.T. Reker, K. Chamberlain (red.), Exploring Existential Meaning. Optimizing Human Development across the Life Span (s. 1-4). Thousand Oaks: Sage Publication.

Ryff C.D. (2014), Psychological well-being revisited: Advances in the science and practice of eudaimonia. Psychotherapy and Psychosomatics, 25, 10-28.

Ryff C.D., Singer B.H. (2008), Know thyself and become what you are: A eudaimonic approach to psychological well-being. Journal of Happiness Studies, 9, 13-39, doi: 10.1007/s10902-006-9019-0104.

Staudinger U.M., Smith J., Baltes P.B. (1992), Wisdom-related knowledge in a life review task: Age differences and the role of professional specialization. Psychology and Aging, 7, 271-281.

Steuden S. (2011), Psychologia starzenia się i starości. Warszawa: Wydawnictwo Naukowe PWN.

Straś-Romanowska M. (2011), Późna dorosłość. W: J. Trempała (red.), Psychologia rozwoju człowieka (s. 326-350). Warszawa: Wydawnictwo Naukowe PWN.

Susułowska M. (1989), Zadowolenie z życia i bilans życiowy ludzi starych. W: M. Susułowska, Psychologia starzenia się i starości (s. 302-326). Warszawa: Wydawnictwo Naukowe PWN.

Tornstam L. (1999), Late-life transcendence: A new developmental perspective on ageing. W: L.E. Thomas, S.A. Eisendandler (red.), Religion, belief and spirituality in late life (s. 178-201). New York: Springer. 